\title{
HUMANISTIC INFORMATION STUDIES: A PROPOSAL
}

\author{
Harry Kunneman \\ University of Humanistic Studies, Utrecht, Netherlands \\ E-mail: H.Kunemman@UvH.nl
}

\begin{abstract}
In this two-part paper I want to introduce a conceptual framework for Humanistic Information Studies. This framework is provisional. As it stands, its main use is to show a path for the further development of Information Studies in a critical and humanistic direction. In the first part of this two-part paper, I will focus on the epistemological questions connected with the conceptual foundations of Humanistic Information Studies (or HIS): what are the characteristics of the specific form of knowledge sought after in HIS. In the second part I will further elaborate the proposal developed in the first part from the standpoint of the specific, form of normative professionalism and of organizational transformation sought after and furthered by Humanistic Information Studies.
\end{abstract}

Key-words: Humanistic studies. Information studies. Modes of knowledge

\section{ESTUDOS HUMANISTICOS DA INFORMAÇÃO: UMA PROPOSTA}

\section{Resumo}

Neste artigo, composto por duas partes, pretende-se introduzir uma quadro conceitual para os Estudos Humanísticos da Informação. Esta quadro é provisório. Do modo como está apresentado sua função principal é indicar um caminho para o desenvolvimento dos Estudos da Informação em um sentido crítico e humanista. A primeira parte do artigo concentram-se em questões epistemológicas relacionadas com fundamentos conceituais dos Estudos Humanísticos da Informação (EHI): quais são as características da específica forma de conhecimento buscadas para os EHI. Na segunda parte trata-se do desenvolvimento da proposta apresentada na primeira, partindo de um ponto de vista específico, a saber, uma forma de profissionalismo normativo e de transformação organizacional, buscados e promovidos pelos Estudos Humanísticos da Informação.

Palavras-chave: Estudos humanísticos. Estudos da Informação. Modos do conhecimento

\section{Two levels}

Before proposing a preliminary definition of Humanistic Information Studies, I start with an indication of the importance of Information Studies, as the field of study upon which Humanistic Information Studies are grafted. The wider importance of Information Studies as such, hinges on the fact that this field provides a rich inroad to central questions of our time on two related levels. The first level is descriptive. The informational dynamic that is both the prime object and the central resource of information studies, is no doubt one of the strongest forces in present day world society (TOURAINE, 1971; CASTELLS, 1996, 1998; FUCHS,

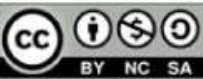


2008). To start with, it obviously has a very strong influence within the sciences. During the last four decades it has fueled the emergence of a complex multidisciplinary field, comprised of different discipline focusing among others on the nature of information, its (digital) transmission and storage and its many different roles in present day societies. Moreover, it is a very dynamic field of economic and technological innovation, not only in the domains of hardware and software development, but also for instance in telecommunication, healthcare and education, in military technology and espionage and in completely new domains such as the description and manipulation of genetic information at the molecular level in genomics. In the third place, closely connected with the second point, the informational dynamic also exerts an enormous social and cultural influence, as witnessed especially by the new informational networks that have emerged from the spread of internet and by the new personalized forms of electronic communication by means of cellphones and tablets. Last but not least, the informational dynamic has very great political consequences, connected on the one hand with human rights - especially the right to freely gather, spread and investigate information - and on the other hand with all political questions concerning the new possibilities to manipulate, distort and hide information.

These political questions lead up to the second level at which Information Studies provides a rich inroad to central developments and transformations of our time. This level concerns all normative and moral questions connected with the informational dynamic. Seen from a normative perspective, this dynamic appears to be highly ambivalent. On the one hand it opens new, unprecedented possibilities for creating new connections between people, furthering new forms of communication and cooperation and for supporting and strengthening freedom and democracy. On the other hand it is clearly connected with new forms of economic power, new forms of inequality, and with new forms of disconnection and alienation (GLOTZ, 1999, CASTELLS, 2002, FUCHS, 2009). But on a descriptive and on a normative level, Information Studies thus embody a crucially important field of research and critical reflection.

\section{A double complexity}

This short introduction leads to a first, preliminary definition of Humanistic Information Studies. HIS, we could say as a first approach, aims to connect the descriptive (and explanatory) study of the informational dynamic that is transforming our societies with 
critical reflection on the ethical, moral and political questions internally connected with this dynamic. This preliminary definition implies that Humanistic Information Studies have to confront and connect two different forms of complexity:

a) In the first place HIS have to face the empirical complexity characterizing the informational dynamic. The informational society that is emerging on a worldwide scale and its innovational dynamic show all the empirical characteristics of a complex system (CILLIERS, 1998; MORIN, 2008). It consists of many interacting parts, it is characterized by non-linearity, it exhibits emergent properties and developments and it allows for many different, non-equivalent conceptualizations that feed into the complexity they try to clarify and understand. This implies that HIS, in order to do justice to this empirical complexity, have to be developed along interdisciplinary lines, based on the cooperation of a broad range of different disciplines from the natural sciences, the social sciences and the humanities.

b) Apart from, but also intertwined with tackling this empirical complexity, HID also have to confront the ethical complexity showing itself in all the ethical, moral and political questions connected with the informational dynamic. It is clear that this dynamic involves many different interests and values, and evokes both great hopes and great fears. The question then arises, what values could orient critical reflection on the ethical and moral questions connected with the informational dynamic.

\section{A prima facie obstacle}

This sketch of the double complexity - both empirical and ethical - that Humanistic Information Studies have to deal with, brings us to a prima facie obstacle for the further development of HIS. This obstacle concerns the lack of connection between, broadly speaking, science and technology on the one hand and humanistic studies on the other hand. This gap has a long history, dating back at least to the hierarchy within ancient Greek Philosophy between 'techne' and 'sofia', as articulated for instance by Plato in The Republic. Since then it has been reiterated many times and in many different forms, for instance in terms of the opposition between 'explanation' and 'understanding' (DILTHEY, 1999 (1895)); in terms of the gap between 'two cultures' (SNOW, 1998 (1959)) and in terms of the struggle between 'positivism' and 'critical theory' (HABERMAS, 1972). To clarify the different articulations of this opposition, it is useful to situate them between two poles, which could be 
designated as 'reductionism' and 'culturalism' respectively. Reductionism rests on two related presuppositions. An early articulation of the first presupposition underlying reductionism can be found in the work of the famous nineteenth century mathematician Marquis de Laplace. In his Philosophical Essay on Probabilities, first published in 1847, he provides the following summary of his reductionist worldview:

We must therefore regard the present state of the universe as the effect of its preceding state and as the cause of the one which is to foll [...] The human mind, in the perfection which it has been able to give to astronomy [has come] within reach of including within the same analytical formulae all the past and future states of the world system. By applying the same method to various other object of its knowledge, it has managed to reduce the observed phenomena to general laws, and to predict the results which must be generated by any given set of circumstances...This onward tendency, peculiar to the human race, is what makes us superior to the animals; it is progress in this area which distinguishes nations and epochs in their true glory. (LAPLACE, 1902 (1847), p. vi)

Reducing the observed phenomena to general laws' and regarding such laws as the only valid form of scientific knowledge, is an apt formulation of the first presupposition of the reductionist worldview, as formulated with great clarity by de Laplace and reiterated by many other scientist and philosophers in different forms. Reductionism however not only involves 'reducing observed phenomena to general laws,' but also involves a second even more radical presupposition: observed phenomena have to be explained on the basis of the properties of the most elementary parts of the objects or systems involved. This implies that physical laws provide the basis for chemical laws, for biological laws and for all phenomena studied by the social sciences. Valid scientific explanation should go from the most fundamental level up to the higher levels, never from the higher levels downwards. A good example of this reductionist movement is provided by present day neurobiology. To understand the brain and the mind, we have to turn to molecular biology, to the physical and chemical properties of neurons and neurotransmitters. If we understand the laws operative on this basic level, we can explain the higher, more complex processes of thinking and feeling by reducing them to lawful regularities at this level. So within the framework of reductionism, causal explanation should always proceed from higher levels of complexity to lower, more basic levels, ending finally on the level of atoms, particles and quantum mechanics.

It is immediately clear that in such a reductionist framework, humanistic studies and all the value-riddled questions they address are banned from the realm of science. This deprecating movement is retaliated in kind however from the other, 'culturalistic' pole of the 
opposition. At this opposite pole, the humanities are deemed the only worthwhile form of intellectual effort. Compared to understanding and interpreting Plato, Shakespeare, Keats and studying, the historical context in which their work could develop, science and technology appear as mundane and even quit trivial endeavors, based on solving technical puzzles and constructing mindless machines. This kind of work might be indispensable, but has nevertheless far less cultural and human significance then the study of literature, history and philosophy. In his famous essay on The Two Cultures, C.P. Snow illustrates this 'culturalistic arrogance' with the following anecdote:

A good many times I have been present at gatherings of people who, by the standards of the traditional culture, are thought highly educated and who have with considerable gusto been expressing their incredulity at the illiteracy of scientists. Once or twice I have been provoked and have asked the company how many of them could describe the Second Law of Thermodynamics. The response was cold: it was also negative. Yet I was asking something which is the scientific equivalent of: Have you read a work of Shakespeare's? (SNOW, 1998 (1959))

Seen in this light the lack of connection and of fruitful intellectual exchange between science and technology on the one hand and humanistic studies on the other hand, not only has a long history, but is also energized and reproduced from both sides of the opposition.

The continuing influence of this opposition both in present day universities and in the wider culture, might at first sight seem to present a formidable obstacle for the development of Humanistic Information Studies as an interdisciplinary endeavor that aims to address both the empirical and the ethical complexity of the informational dynamic. This would be too hasty a conclusion however: the informational dynamic itself, as a technological, social and cultural development also offers new impulses and possibilities to overcome this opposition.

On the one hand, it has no doubt continued and confirmed it, for example in the form of the academic distance between cybernetics and information science on the one hand and research within Cultural Studies and related disciplines into the dynamics of the informational society on the other hand. But it is important to see that the informational dynamic also provides new impulses and opportunities to leave this opposition behind and supersede the distrust of and disdain for the 'other' pole, connected with reductionism and culturalism alike. In the remainder of my argument I will try to clarify these new impulses and opportunities in three steps. The first step concerns the transformations connected with the digitalization and democratization of information and communication and the concomitant decline of the traditional book-oriented 'humanistic culture'. In a second step I will then situate this transformation in the context of a wider scientific and social development, to wit the spread of 
a new form of knowledge production, often designated as 'Mode 2 science' (GIBBONS C.S. 1992). In a third step I will argue that the new interpenetration between 'traditional' scientific and technological knowledge bound to disciplinary demarcations on the one hand ('Mode 1') and new forms of scientific knowledge production that 'absorb' social interests and values on the other hand ('Mode 2'), has stimulated the development of new forms of ethical and moral knowledge and insight in the context of scientific and technological knowledge production. This new form of knowledge, designated by several authors as 'Mode 3 knowledge', is of central important for the development of Humanistic Information studies, because it provides an answer to the crucial question posed above, with regard to the values that can orient critical reflection on the ethical and moral questions connected with the informational dynamic.

\section{Transformations}

In the first part of my argument, I have tried to clarify the importance and aim of Humanistic Information Studies by way of three related dichotomies. Firstly the empirical and normative questions to which Information Studies provide a rich inroad. In the second place the two different forms of complexity - empirical and ethical - confronting HIS when it endeavors to connect empirical and normative questions with each other. And lastly the lack of connection between science and technology on the one hand and humanistic studies on the other hand, which I have elucidated by way of the underlying opposition between two poles: reductionism and culturalism.

Seen against the background of these dichotomies, one of the fascinating aspects of the informational dynamic that is transforming modern societies under our very eyes is the fact that it also strongly contributes to the transformation of deeply entrenched epistemological and cultural frameworks underlying these dichotomies.

A vivid illustration of this transformation is provided by the 'democratization' of culture that has gone hand in hand with the increasing digitalization of cultural artifacts, especially books and music, but also paintings and pictures. The cultural arrogance and 'scientific illiteracy' of 'traditional' literary intellectuals criticized so lucidly by C.P. Snow, was part of an elitist culture, oriented chiefly to printed forms of information, in particular to physical books. The digitalization of information characterizing the informational society is rapidly undermining the social significance and the influence of this humanistic, bookoriented and more or less elitist culture. In our times, informational technologies and the 
underlying scientific developments are reaching into the pores of everyday life and are rapidly transforming the life world of an ever-increasing number of citizens all around the globe. The I-phone and I-pad and all their emulations and permutations, provide one of the most telling illustrations of this penetration of informational technology into the life world of most citizens, both in Western countries and in 'developing' countries all around the globe. This process, in all its ambivalence, also contributes to a far-reaching democratization of the accessibility of all kinds of information, knowledge and cultural resources that formerly were accessible only to cultural elite. Moreover, together with other scientific and technological developments in areas such as health, food transportation and sustainability, the technological innovations underlying the informational transformation of the life world have put an end to the culturalistic image of science and technology as more or less trivial endeavors, based on solving technical puzzles and constructing mindless machines. Science and technology have become the most important economic, cultural and social force determining the shape and course of modern and modernizing societies all over the world. As a consequence, the humanities and the book-oriented 'interpretative' values cherished by them are under grave pressure nowadays. In some countries they are even threatened by cultural and scientific

marginalization. Ironically, the newly founded digital humanities are rapidly becoming one of the most flourishing forms of 'humanistic study', at the expense of more traditional, text bound humanistic studies. Equally telling, 'post-humanism' has become a trendy topic in contemporary postmodern philosophy and within cultural studies (HAYLES, 1999; BRAIDOTTI, 2013).

\section{A new mode of knowledge production}

The informational dynamic has not only contributed to the transformation of the deeply entrenched epistemological and cultural frameworks connected with the opposition between the sciences and the humanities. It has also contributed to the emergence of new possibilities for re-connecting the development of scientific knowledge with humanistic values and insights. In comparison with the early forms of humanism that emerged in fourteenth-century Europe, the book-centered humanism of the 'literate intellectuals' is an impoverished form of humanism. Great Renaissance-humanists such as Pico de Mirandola and Leonardo da Vinci connected as a matter of course art and literature with scientific inquiry and a passion for technological innovations. In the course of the modernization process this connection is gradually weakened, and has even developed into an opposition, 
culminating in the clash between 'the two cultures'. In the past decades however, in the wake of the far-reaching technological innovations that led to the development of the informational society, new possibilities have emerged for reconnecting the sciences and the humanities, but also a new urgency to develop such connections. To elucidate these new possibilities, I will go deeper into the new mode of knowledge production that has emerged during the last decades, in remarkable 'sync' with the rise of the informational society.

\section{Mode 1 and Mode 2}

The distinction between two modes of production of scientific knowledge - first introduced by Gibbons et al. in 1994 in their book The New Production of Knowledge (GIBBONS et al, 1994) and further elaborated by Nowotny, Scott and Gibbons (2001) provides a good point of departure for clarifying the new possibilities for reconnecting the sciences and the humanities that have emerged in the wake of the informational dynamic. The distinction 'Mode 1' and 'Mode 2' has been developed in order to do justice to the profound changes in the nature and legitimation of scientific knowledge that have occurred in modern societies in the last decades of the twentieth century. In his path-breaking book La Condition Postmoderne, Jean-Francois Lyotard provided one of the first articulations of this change in terms of the demise of the traditional legitimations of scientific knowledge and the new dominance of what he calls 'performativity' or 'the technological criterion' (LYOTARD, 1979). Science has to be useful and contribute to economic progress. Thus it gets entangled openly in dominant relations of power: who decides what is useful and what contributes to economic progress and what not? Lyotard's early articulation of the inner relation between knowledge and power in the sciences, together with Michel Foucault's equally influential analysis of the truth-power nexus in the social sciences (Foucault 1978, 1981), has provided a fertile soil for the development of a host of critical analyses in the philosophy and sociology of science during the eighties of the last century, culminating in the rapid spread of social constructionist perspectives on science and technology from the nineties onward (LATOUR; WOOLGAR, 1986; LATOUR, 1987; KNORR CETINA, 1993). The introduction of the distinction between Mode 1 and Mode 2 knowledge-production was closely linked to this broader development. But it also introduced a new voice in this critical chorus that is very relevant in my eyes for the further development of Humanistic Information Studies. To clarify this relevance I will have to go somewhat deeper into the distinction between Mode 1 and Mode. $^{1}$

\footnotetext{
${ }^{1}$ The next paragraph is based on part on an earlier publication: cf. Harry Kunneman \& Peter Derkx (2013).
} 
According to Gibbons et al., Mode 1 knowledge production is oriented towards questions and problems defined by scientific communities connected with specific academic disciplines, such as physics, chemistry and biology. In contrast, Mode 2 knowledge production is oriented toward the solution of practical problems, such as the development of new medicines, faster computer chips, new weapon systems or more sustainable forms of energy-production. Thus Mode 1 science is mono-disciplinary and governed by the methodological standards of specific disciplines as defined by handbooks and by reviewing boards of leading journals. In contrast, Mode 2 science is characterized by its interdisciplinary character and by the dynamic and heterogeneous character of the research communities involved. Most importantly however, Mode 2 science is 'monitored' by a multiplicity of different stakeholders that judge the adequacy of possible solutions for the practical problems at stake from different perspectives, involving diverging interests and values. According to Gibbons et al. (1994), these tensions and conflicts provoke new forms of social reflexivity regarding the development of science and technology. The fact that in Mode 2 knowledge production different stakeholders are involved in agenda setting and quality assessment implies that they have to provide a legitimation for their specific take on the questions involved and have to defend their perspective in critical dialogue, or sometimes in open conflict with, the perspective of other stakeholders. Contemporary debates on the advantages and potential risks of genetic manipulation, or on the causes and risks of climate change, provide clear examples of the new forms of 'social reflexivity' connected with the rise and spread of Mode 2 science. The former monopoly of communities of scientific experts in judging the 'verisimilitude' and scientific relevance of theories and empirical results characteristic of 'Mode 1 science', is replaced in Mode 2 by more reflexive and - according to Gibbons c.s - also more dialogical and democratic forms of interaction between different social groups having (or claiming) a 'stake' in specific forms of science-based problem solving.

In my eyes, this distinction between Mode 1 and Mode 2 Science offers an important conceptual advantage in in comparison with other 'constructionist' approaches in the philosophy and sociology of science: it holds on to the relative autonomy of Mode 1 science. In most versions of contemporary constructivism and constructionism, all forms of scientific knowledge are analyzed as socially constructs that are completely mixed up with normativity and power. In my eyes, such an analysis is problematic in so far as it cannot explain why some scientific 'constructions' are so remarkably stable and robust. The basic tenets of Newton's optics for example, or the second Law of Thermodynamics or the 'double helix' 
structure of chromosomes, seem to withstand so far all efforts to socially reconstruct them in view of the very limited range of stakeholders and the asymmetrical forms of 'epistemological power' involved in their 'construction'. By distinguishing between Mode 1 and Mode 2 knowledge, one can do justice to the fact that modern science has different 'faces' (to borrow and amend Latour's analysis of the 'Janus-face' of science (LATOUR, 1987). On the one hand a face showing relatively independent scientific communities that control their own research agenda building on specific disciplinary histories and paradigmatic results and regularly succeed in describing and explaining previously unknown or unexplainable stable patterns in our world, in empirical and mathematical forms that are themselves remarkably stable (Radder...) On the other hand a different, constructive face, oriented towards the interdisciplinary and trans-disciplinary development of new knowledge and techniques that allow for the (often temporary) solution of practical problems, defined to a great extent by powerful social actors such as big companies, national governments and big universities, and to a lesser extent by other, social and political stakeholders such as NGO's.

\section{Mode 3 knowledge}

The conceptual advantage thus offered by the distinction between Mode 1 and Mode 2 Science is connected however with a severe drawback. In my eyes, the analysis of Mode 2 knowledge production as developed by Nowotny and her collaborators is too naïve in a moral and political sense. They suggest that the rise of Mode 2 science opens up new possibilities for strengthening democratic influences on the production of scientific knowledge. But it remains unclear how to prevent the deterioration of the exchanges and discussions between different "stakeholders' with regard to the content of Mode 2 knowledge into strategic struggles for power. Empirically this deterioration is highly probable, in view of the big differences in resources between, on the one hand, big corporations, governments and universities; on the other hand NGO's and other stakeholders from civil society.

In the light of this 'democratic deficit' with regard to Mode 2 knowledge production, several authors have suggested the need for a third mode of knowledge production, 'Mode 3', that should safeguard a bottom-up dynamic, rooted in local communities and cultural resources and providing 'countervailing power' against the top-down influence of the most powerful stakeholders in shaping the content of Mode 2 knowledge (JIMENEZ, 2008; CARAYANNIS; BARTH; CAMPBELL, 2012). In my own version of the idea of Mode 3 knowledge (KUNNEMAN, 2005a, 2005b, 2010, 2013), I have taken a different path, 
centering on the role of professionals and organizational cultures in the development and implementation of Mode 3 knowledge. The exploration of this path was prompted among others by my discontent with critical analyses focusing on civil society and the 'life world' as the exclusive locus of political resistance and political progress. Jürgen Habermas' analysis of the colonization of the life world by economic and bureaucratic systems provides a very influential example of this type of political analysis (HABERMAS, 1981, 1986). According to Habermas, moral guidelines that transcend particular interests can only result from open processes of democratic deliberation, that is: from communicative action not distorted by unequal relations of power. In this perspective, the life world, in particular civil society, provides the only social domain where communicative action and democratic deliberation can flourish. This implies that the 'colonization' of the life world by economic and bureaucratic systems, can only be countered from with the life world itself, by means of open communication and democratic deliberation. Most versions of the idea of Mode 3 knowledge that have been developed during the last decade, explicitly or implicitly presuppose such a dichotomous model of 'system' versus 'life world', or dominant 'top-down' economic and political interest versus 'bottom-up' democratic movements and deliberative processes. My own exploration of this idea focuses instead on the pivotal role played by professionals and organizational cultures in the many forms of interference and mediation between systems and life worlds. In the light of the importance and extent of this mediation, I have proposed to distinguish a zone of interference as a third domain situated in-between systems and life world (KUNNEMAN, 1996, 2004, 2005a). This transitional zone is populated by organizations and professionals that grapple with the interference between two different 'logics' that demand their allegiance on different, but equally legitimate grounds: the logic of the systems and their characteristic curtailing of deliberation and dialogue on the one hand and the communicative and dialogical 'logic' of the life world on the other hand. When Habermas' binary opposition between system and life world is substituted by this three-fold scheme, it becomes possible to develop a situational interpretation of the colonization of the life world and of concrete efforts to subvert this colonization. The situational character of the interference between different logics in the transitional zone between system and life world, implies that it is not certain beforehand whether the logic of the systems will take central stage or whether the communicative logic of the life world will prevail at specific moments in specific situations.

The outcome of the interference between them is to a certain extent open and can change in time, and can even vary between different parts of organizations or at different times during the workday of a professional. This openness and variation are closely connected 
to the pivotal role played by professionals and by the moral poverty or richness of organizational cultures in shaping these situational outcomes. In two-way interaction with organizational cultures, professionals make all kinds of normative choices in their day to day practice with regard to the 'push and pull' of the systemic and communicative logics competing for their allegiance.

These normative choices of professionals and the moral poverty or richness of organizational cultures that feed into these choices are of central importance for my version of Mode 3 knowledge. Instead of defining Mode 3 knowledge in terms of bottom-up influences on the content and development of scientific knowledge stemming from local movements and deliberative processes in the life world, I propose to situate the development of Mode 3 knowledge in the zone of transition between systems and life world, and define it in terms of moral resources and insights contained in organizational cultures and brought to bear by professionals on the actual development of Mode 1 and Mode 2 knowledge. These moral resources and insights stem in part from 'bottom up' processes rooted in local movements, deliberative processes and cultural developments in the life world. But this is only half the story. Professionals and organizations can 'absorb' and assimilate these moral resources, but they have to connect them with scientific and professional expertise and embed them in organizational work-processes, in order to actually influence or redirect the construction of new scientific knowledge and of technological innovations on the level of content.

Foregrounding this active, mediating role of professionals and organizational cultures in bringing Mode 3 knowledge to bear on the actual construction of scientific knowledge and technological innovations brings several advantages with it. To start with in this way the risk is avoided that Mode 3 knowledge is pictured as a specific form of knowledge that can be defined and understood in separation from Mode 1 and Mode 2. In my eyes, such a separation is no doubt useful and illuminating with regard to the Mode 1 and Mode 2 knowledge. As argued above, there exists a real and important difference between them, which I have tried to capture by means of the two faces of present day science, characterized by pattern-centered versus construction-centered knowledge development respectively. In contrast, Mode 3 knowledge cannot stand on its own, but can only develop and function in relation to specific developmental pathways of Mode 1 or Mode 2 knowledge. In other words: Mode 3 knowledge can only exist as a transforming addendum to and mixed with either Mode 1 or Mode 2 knowledge.

This defining characteristic of Mode 3 knowledge is closely connected with the second conceptual advantage that can be gained by foregrounding the mediating role of professionals 
and organizational cultures. By defining Mode 3 knowledge along these lines, more light is shed on the new possibilities for connecting the sciences and the humanities flowing from the informational dynamic. As argued above, the cultural arrogance and 'scientific illiteracy' characteristic of the traditional humanistic perspective, were closely tied to the 'bookoriented' interpretive values that have dominated the humanities for so long. Even the distinction between system and life world introduced by Habermas in the eighties of the last century, shows traces from this 'culturalistic' bias, as transpires from the fact that Habermas connects culture and meaning with communicative action in the life world, and associates technology, economy and bureaucracy with the suppression of meaning, values and culture.

Over and against such a traditional humanistic perspective, we have to recognize in my eyes that the far-reaching technological innovations and social changes connected with the emergence of the informational society have also created possibilities for developing new connections between the sciences and the humanities. These new possibilities have not been initiated at the side of the humanities, but at the side of science and technology. The philosophical and sociological reflections with regard to the different modes of knowledge

production, point without exception to the inner connection between the steadily increasing economic and political import of science and technology and the rise and spread of Mode 2 science. The same primacy underlies my efforts to define Mode 3 knowledge as internally connected with the production of either Mode1 or Mode 2 knowledge. As I will argue in the concluding paragraph, strengthening these connections is of crucial importance for the further development of Humanistic Information Studies.

\section{Conclusion: how to further the development of Humanistic Information Studies?}

I started this proposal with a preliminary definition of HIS, based on the distinction between descriptive and normative questions raised by the informational dynamic: in my eyes HIS should connect the descriptive (and explanatory) study of the informational dynamic with critical reflection on the ethical, moral and political questions internally connected with this dynamic. This aim, I have argued, implies the necessity for Humanistic Information Studiers to confront a double complexity: on the one hand the empirical complexity of the innovational dynamic connected with the emergence of the informational society; on the other hand the ethical complexity showing itself in all the ethical, moral and political questions connected with this innovational dynamic. In a third step I have sketched a prima facie obstacle for the further development of HIS, flowing from the lack of connection between science and 
technology on the one hand and humanistic studies on the other hand. The deep gap separating reductionism and culturalism as competing, mutually exclusive perspectives provides a telling illustration of this lack of connection. However, the scientific and technological innovations underlying the emergence of the informational society have also created unexpected opportunities for developing new connections between the sciences and the humanities. Building on the distinction between Mode 1 and Mode 2 knowledge, I have tried to clarify these new opportunities by way of the idea of Mode 3 knowledge, which I propose to define in terms of moral resources and insights contained and articulated in organizational cultures and brought to bear by professionals on the actual development of Mode 1 and Mode 2 knowledge in the zone of transition between system and life world.

Against this background I can now bring my sketch of the epistemological foundations of HIS to a preliminary conclusion. The foregoing sketch implies that the 'site' or 'place' where humanism and humanistic values can flourish has undergone a dramatic change. Instead of the life world, academia and the arts as the privileged 'sites' and 'soil' for the articulation and transfer of humanistic, interpretative and 'dialogical' values and the defense of justice and democracy, the zone of transition between system and life world is becoming the most important site where humanistic values can and have to flourish. Here, in this zone of interference, professionals and organizations oriented up to a point by humanistic values, struggle to connect the systemic logic characterized by the curtailing of deliberation and dialogue on the one hand and the communicative and dialogical 'logic' of the life world on the other hand, on the level of the content of the work they do and of the knowledge this work is based on. In other words: the values traditionally associated with humanism and humanistic studies have to defended and developed in present day, informational societies, primarily in the zone of transition between system and life world, on the level of the culture of organizations and the normative decisions of professionals that shape the content of the knowledge-led work they do. This analysis allows at last for a clear answer to the question posed in the introduction with regard to the characteristics of the specific form of knowledge sought after in HIS.

By way of preliminary conclusion, I would like to characterize this form of knowledge as follows: Humanistic Information Studies aim to enrich the different forms of knowledge production (Mode 1 and Mode 2) that propel the informational dynamic with Mode 3 knowledge, that is with moral resources and insights articulated in organizational cultures and brought to bear by professionals on the actual development of Mode 1 and Mode 2 knowledge in view of furthering a meaningful life, just social bonds and a sustainable world society. 


\section{References}

Braidotti, R. (2012). The posthuman. Cambridge: Polity Press, 2013.

Carayannis, Elias G.; Barth, Thorsten D.; Campbell, David F.J. (2012). The quintuple helix innovation model: global warming as a challenge and driver for innovation. Journal of Innovation and Entrepreneurships, 1(2).

Castells, M. (1996). The rise of the network society, the information age: Economy, society and culture, volume I. Oxford: Blackwell Publishers.

Castells, M. (1997). The power of identity, the information age: Economy, society and culture, volume II. Oxford: Blackwell Publishers.

Castells, M. (1998). End of mlilennium, the information age: Economy, society and culture, volume III. Oxford: Blackwell Publishers.Derkx, P., \& Kunneman, H. (Eds.). (2013). Genomics and democracy. towards a 'lingua democratica' for the public debate on genomics. Amsterdam-New York: Rodopi.

Castells, M (2002). The information society and the welfare state: the finish model. Oxford: Oxford Univ. Press, 2002.

Cilliers, P. (1998). Complexity and postmodernism. Understanding complex systems. London: 19 Routledge.

Derkx, P., \& Kunneman, H. (Eds.). (2013). Genomics and democracy. towards a 'lingua democratica' for the public debate on genomics. Amsterdam-New York: Rodopi.

Fuchs, C.(2008). Dialektisches denken als grundlage der kritik des transnationalen informationellen kapitalismus. In: Conference Polyphone Dialektik, 2007. Berlin, Nov. 2007. Proceedings: Ernest Block Association (Org.). VorSchein n.30. Nuremberg: Antogo Verlag, p. 97-119.

Gibbons, M. et al. (1994). The new production of knowledge. the dynamics of science and research in contemporary societies. London, Thousand Oaks, New Delhi: Sage Publications.

Glotz, P. (1999). Die beschleunigte gesellschaft. Kulturkämpfe im digatalen Kapitalismus. München: Kindler Verlang.

Habermas, J. (1985). Reason and racionalisation of society. In: communicative action. Boston: Beacon Press, 1985, v. 1. . The theory of

Habermas, J. (1986). The new obscurity: the crisis of the welfare state. Philosophy and Social Criticism, v. 11, n. 2, p. 1-18.

Hayles, N. K. (1999). How we Became Posthuman. Virtual bodies in cybernetics, literature and informatics. Chicago: Chicago Univ. Press. 
Jimenez, Jaime.(2008). Pesquisa socialmente responsável: podemos falar de um Modo 3 de produção de conhecimento? Reciis, Rio de Janeiro, 2(1) 48-56.

Knorr Cetina, K. (1993). 'Strong constructivism - from a sociologist's point of view'. Social Studies of Science, 23, 555-563.

Kunneman, H. P. J. M. (1996). Van theemutscultuur naar walkman-ego : Contouren van postmoderne individualiteit. Amsterdam: Boom Publishers

Kunneman, H. (2005a). Voorbij het dikke-ik. Amsterdam: SWP/Humanistics University Press.

Kunneman, H. (2005b) 'Social Work as a Laboratory for Normative Professionalization', in: Social work and Society, 3, 2, pp. 191-200

Kunneman, H. (2010). 'Viable alternatives for commercialized science: The case of humanistics.' In H. Radder (Ed.), The commodification of academic research. Science and the modern university (pp. 307-336). Pittsburgh: University of Pittsburgh Press.

Kunneman, H. (2013). Ethical complexity, hermeneutics and mode 3 knowledge. In: Derkx \& Kunneman (Eds.) 2013, pp. 105-129

Kunneman, Harry \& Derkx, Peter (2013), Introduction, in P. Derkx \& H. Kunneman (eds.) Genomics and Democracy. Towards a Lingua Democratica for the Public Debate on Genomics, Rodopi: Amsterdam/New York, p. 8

Laplace, P. S. M. d. (1902 (1847)). Essay on probabilities. New York: Wiley. (Pierre Simon, Marquis de Laplace, Essai philosophique sur les probabilités Translated by John Cottingham from Oeuvres de Laplace, Paris 1847, vol VII, pp vi)

Latour, B. (1987). Science in action: How to follow scientists and engineers through society . Milton Keynes: Open University Press.

Latour, B., \& Woolgar, S. (1986). Laboratory life: The construction of scientific facts . Princeton, N.J.: Princeton University Press.

Lyotard, J-F. (1979). La condition postmoderne. Rapport sur le savoir. Paris: Minuit.

Nowotny, H., Scott, P. K., \& Gibbons, M. (2001). Re-thinking science: Knowledge and the public in an age of uncertainty. Cambridge, UK: Polity.

Snow, C. P. (1998 (1959)). The Two Cultures. Cambridge: Cambridge University Press.

Tourraine, A (1971). The post-industrial society. Tomorrow's history: classes, conflicts in the programmed society. New York: Random House, 1971.

\section{Referências}

BRAIDOTTI, Rosi. The posthuman. Cambridge: Polity Press, 2013. 
CARAYANNIS, Elias G.; BARTH, Thorsten D.; CAMPBELL, David F.J. The quintuple helix innovation model: global warming as a challenge and driver for innovation. Journal of Innovation and Entrepreneurships, v 1, n.2, p. 2-12, Springer 2012. Disponível em: $<$ http://www.innovation-entrepreneurship.com/content/1/1/2>. Acesso em: 13 jan. 2015.

CASTELLS, Manuel. End of millennium, the information age. In: Economy, society and culture, Oxford: Blackwell Publishers, 1998. v. 3.

CASTELLS, Manuel. The information society and the welfare state: the finish model. Oxford: Oxford Univ. Press, 2002.

CASTELLS, Manuel. The power of identity, the information age. In: society and culture. Oxford: Blackwell Publishers, 1997, v. 2. . Economy,

CASTELLS, Manuel. The rise of the network society, the information age. In:

Economy, society and culture. Oxford: Blackwell Publishers, 1996, v. 1.

CILLIERS, P. Complexity and postmodernism: understanding complex systems. London: Routledge, 1998

DERKX, P.; KUNNEMAN, H. (Eds.). Genomics and democracy: towards a 'lingua democratica' for the public debate on genomics. Amsterdam-New York: Rodopi, 2013.

FUCHS, Christian. Dialektisches denken als grundlage der kritik des transnationalen informationellen kapitalismus. In: CONFERENCE POLYPHONE DIALEKTIK, 1., 2007. Berlin. Proceedings ... Ernest Block Association (Org.). VorSchein n.30. Nuremberg: Antogo Verlag, 2008, p. 97-119.

GIBBONS, M. et al. The new production of knowledge: the dynamics of science and research in contemporary societies. London: Thousand Oaks / New Delhi: Sage Publications, 1994.

GLOTZ, Peter. Die beschleunigte gesellschaft: kulturkämpfe im digatalen kapitalismus. München: Kindler Verlang, 1999.

HABERMAS, Jürgen. The new obscurity: the crisis of the welfare state. Philosophy and Social Criticism, v. 11, n. 2, p. 1-18, 1986. Disponível em:

$<$ http://philpapers.org/rec/HABTNO >. Acesso em: 15 jan. 2015.

HABERMAS, Jürgen. Reason and racionalisation of society. In: communicative action. Boston: Beacon Press, 1985, v. 1. . The theory of

HAYLES, N. Katherine. How we became posthuman: virtual bodies in cybernetics, literature and informatics. Chicago: Chicago Univ. Press, 1999

JIMENEZ, Jaime. Pesquisa socialmente responsável: podemos falar de um Modo 3 de produção de conhecimento? Reciis, v. 2, n.1, p. 48-56, jan./jun.2008. Disponível em: $<$ http://www.reciis.icict.fiocruz.br/index.php/reciis/article/view/145/139>. Acesso em: 15 jan. 2015. 
KNORR CETINA, K. Strong constructivism :from a sociologist's point of view. Social Studies of Science, v. 23, n.3, p. 555-563, Aug.1993. Disponível em: $<$ http://sss.sagepub.com/content/23/3.toc $>$. doi:10.1177/0306312793023003003. Acesso em 13 de jan. de 2015.

KUNNEMAN, Harry. P.J.M. Ethical complexity, hermeneutics and mode 3 knowledge. In: DERKX, P.; KUNNEMAN, H. (Eds.). Genomics and democracy: towards a 'lingua democratica' for the public debate on genomics. Amsterdam-New York: Rodopi, 2013, p. 104-132.

KUNNEMAN, Harry. P.J.M. Introduction. In: DERKX, P.; KUNNEMAN, H. (Eds.). Genomics and democracy: towards a 'lingua democratica' for the public debate on genomics. Amsterdam-New York: Rodopi, 2013, p. 8-34.

KUNNEMAN, Harry. P.J.M. Social work as a laboratory for normative professionalization. Social Work and Society, v. 3, n. 2, p. 191-200, 2005b. Disponível em:

$<$ http://www.socwork.net/sws/article/view/194/481>. Acesso em 13 de jan. de 2015.

KUNNEMAN, Harry. P.J.M. Van theemutscultuur naar walkman-ego:cContouren van postmoderne individualiteit. Amsterdam: Boom Publishers, 1996.

KUNNEMAN, Harry. P.J.M. Viable alternatives for commercialized science: The case of humanistics. In: H. Radder (Ed.). The commodification of academic research: science and the modern university. Pittsburgh: University of Pittsburgh Press, 2010, p. 307-336.

KUNNEMAN, H. Voorbij het dikke-ik. Amsterdam: SWP/Humanistics Univ.Press, 2005a.

LAPLACE, P. S. M. D. (1847). Essay on probabilities. Tradução de John Cottingham. New York: Wiley, 1902. (Original: Pierre Simon, Marquis de Laplace. Essai philosophique sur les probabilités. In: . Oeuvres de Laplace, Paris 1847, v. 7).

LATOUR, B. Science in action: How to follow scientists and engineers through society. Milton Keynes: Open University Press, 1987.

LYOTARD, Jean- François. La condition postmoderne: rapport sur le savoir. Paris: Minuit, 1979. (Coleção: Critique).

LATOUR, B.; WOOLGAR, S. Laboratory life: the construction of scientific facts. Princeton, N.J.: Princeton University Press, 1986.

NOWOTNY, H.; SCOTT, P. K.; GIBBONS, M. Re-thinking science: knowledge and the public in an age of uncertainty . Cambridge (UK): Polity, 2001.

SNOW, C. P. (1959). The two cultures. Cambridge: Cambridge University Press, 1998.

TOURRAINE, Alain. The post-industrial society. Tomorrow's history: classes, conflicts in the programmed society. New York: Random House, 1971. 